\title{
Family Environment and Psychological Adaptation in Adolescents
}

\author{
Ambiente Familiar e Adaptação Psicológica em Adolescentes
}

\author{
Juliana Burges Sbicigo* \& Débora Dalbosco Dell'Aglio \\ Universidade Federal do Rio Grande do Sul, Porto Alegre, Brasil
}

\begin{abstract}
The association between quality of family relationships and psychological adjustment has been understudied in the literature. This study tested the predictive relationship between family environment (measured by the dimensions of cohesion, hierarchy, support and conflict) and indicators of psychological adjustment (self-esteem, general self-efficacy and low levels of self-depreciation) in adolescents using structural equation modeling. Participants were 656 students aged between 12 and 18 years old from public schools. They answered the Family Climate Inventory, Rosenberg Self-Esteem Scale and General Perceived Self-efficacy Scale. The results indicated that the family environment (cohesion, support and low conflict) was a significant predictor of psychological adaptation. This study concluded that functional family relationships are important for the expression of positive psychological characteristics during adolescence.

Keywords: Family relations, self-esteem, self-efficacy, adolescent.
\end{abstract}

\begin{abstract}
Resumo
A associação entre qualidade das relações familiares e adaptação psicológica tem sido subinvestigada na literatura. Esta pesquisa testou a relação preditiva entre ambiente familiar (através das dimensões coesão, hierarquia, apoio e conflito) e indicadores de adaptação psicológica (autoestima, autoeficácia geral e baixos níveis de autodepreciação) em adolescentes utilizando modelagem de equações estruturais. Participaram 656 estudantes de escolas públicas entre 12 e 18 anos, que responderam ao Inventário do Clima Familiar, à Escala de Autoestima de Rosenberg e à Escala de Autoeficácia Geral Percebida. Os resultados indicaram que o ambiente familiar (coesão, apoio e baixos índices de conflito) foi um preditor significativo de adaptação psicológica. Conclui-se que relações familiares funcionais são importantes para a expressão de características psicológicas positivas na adolescência.

Palavras-chave: Relações familiares, autoestima, autoeficácia, adolescente.
\end{abstract}

The influence of family processes in the course of human development is widely recognized in the psychological literature (Collins \& Laursen, 2004; Smetana, Campione-Barr, \& Metzger, 2006). In recent decades, there has been accumulation of evidence suggesting the association between dysfunctional family relationships and adjustment problems in childhood and adolescence (Chedid, Romo, \& Chagnard, 2009). Moreover, the growing expansion of the field of Positive Psychology has increasingly led researchers to investigate the impact of the family on psychological adjustment. Some studies have shown that favorable characteristics of family interactions and parenting are associated with the presence of positive psychological conditions, such as perception

*Endereço para correspondência: Instituto de Psicologia, Departamento de Psicologia do Desenvolvimento e da Personalidade, Universidade Federal do Rio Grande do Sul, Rua Ramiro Barcelos, 2600, sala 115, Porto Alegre, RS, Brasil, 90035-003. E-mail: julianasbicigo@gmail.com e dalbosco@cpovo.net of higher self-esteem (Bean \& Northrup, 2009; Frank, Plunkett, \& Otten, 2010; Musito, Jiménez, \& Murgui, 2007) and self-efficacy (Guo, Deng, Liang, \& Yan, 2009; Hoeltje, Zubrick, Silburn, \& Garton, 1996; Oliver \& Paull, 1995), especially in adolescence.

Among the family characteristics that are relevant to the study of psychological dimensions, those related to the family environment or climate are highlighted, i.e. the individual's perception of the quality of relationships within the family (Teodoro, Allgayer, \& Land, 2009). Assessment of family environment is usually performed based on dimensions such as cohesion, hierarchy, support, and conflict (Björnberg \& Nicholson, 2007; Teodoro et al., 2009). Cohesion is the emotional bond that connects family members, meaning the levels of affection, friendship, and intimacy shared. Hierarchy refers to the structure of power and control between individuals, which mainly reflects the greater influence of older people on family decisions. Support is the perception of the material and emotional support received from the family in face of challenges and problems. As for conflict, it involves a set 
of negative feelings among individuals, which can create stress, hostility, criticism, and aggression within the family. Some studies have suggested that family conflict is inversely related to cohesion and support; however, there is no consensus whether cohesion and hierarchy are independent or related aspects in the dynamics of family interactions (Teodoro et al., 2009; Wood, 1985).

The existence of change or stability in the perception of cohesion, conflict, and hierarchy in adolescence has been widely discussed by theories and studies of psychology of human development (Goede, Branje, \& Meeus, 2009; Smetana et al., 2006). On the one hand, neopsychoanalytic, sociobiological, and cognitive theories claim that the youths' search for autonomy leads to decreased cohesion, more conflicts, and progressive balance in the relations of hierarchy with parents from early adolescence to intermediate adolescence (Goede et al., 2009). Empirical support for this hypothesis is found in recent studies conducted with youths from different ethnic groups (Goede et al., 2009; Matjasko, Grunden, \& Ernest, 2007). On the other hand, socio-relational theories have argued that there is continuity in the emotional bond between youths and their families, instead of withdrawal and exacerbation of conflicts (Collins \& Laursen, 2004). This hypothesis was also empirically supported in studies involving U.S. and European adolescents (Baer, 2002; Buist, Reitz, \& Dekovic, 2010).

In relation to psychological adjustment, self-esteem was defined by Rosenberg (1965) as the personal evaluation of one's value and appropriateness, which is reflected in feelings, thoughts, and attitudes of approval or disapproval of oneself. Although high and low self-esteem have been generally considered as opposite ends of the same continuum, some scholars consider these as separate constructs (i.e., positive self-esteem and self-deprecation) (Boucher, Peng, Shi, \& Wang, 2009; Frank et al., 2010; Greenberger, Chen, Dmitrieva, \& Farruggia, 2003). Boucher et al. (2009) demonstrated that individuals can have positive feelings of self-esteem and self-deprecation simultaneously. The bi-dimensional characteristic of self-esteem has been shown in several studies using the Rosenberg Self-Esteem Scale (Frank et al., 2010; Greenberger et al., 2003). Therefore, the present study considered the two dimensions of this construct.

Individuals with positive self-esteem may feel more optimistic (Rosenberg, 1965) and competent to achieve goals based on their own abilities (Zimmerman \& Cleary, 2005). Those with higher levels of self-depreciation can experience feelings of worthlessness, inferiority, or inadequacy (Rosenberg, 1965), which can result in feelings of incompetence or inability to achieve their goals, resulting in lower self-efficacy.

Therefore, self-esteem and self-efficacy are similar constructs. Self-efficacy consists of a cognitive assessment of the ability to gather cognitive, emotional, and behavioral resources needed to perform a particular task or achieve a goal (Bandura, 1977, 2006), while self-esteem consists of a set of feelings about self-worth (Zimmerman \& Cleary, 2005). Hence, self-esteem reflects the evaluation of personal competence and self-efficacy expresses the evaluation of confidence in such competence. While self-esteem includes beliefs like "I am," "I have," self-efficacy produces beliefs like "I can" (Skaalvik \& Bong, 2003). There is no consensus in the literature on gender differences in the expression of these attributes (Bandura, 2006; Gentile et al., 2009; Souza \& Souza, 2004). However, there are more studies suggesting no differences between boys and girls (Gentile et al., 2009; Souza \& Souza, 2004).

It is noteworthy that in the definition proposed by Bandura $(1977,2006)$, self-efficacy or confidence in the personal competence depends on the specific situation, as a person may feel competent in one situation and incompetent in a different situation. In the 1990s, however, a concept of general self-efficacy (Schwarzer \& Jerusalém, 1995) consisting of a general belief in the ability to successfully perform a variety of tasks and deal with different situations was suggested. Therefore, it is a belief at the level of "trait", which is opposite to the concept suggested by Bandura $(1977,2006)$, according to which self-efficacy is dependent on the specific situation and, thus, a belief at the level of "state". In recent years, both the concept of general self-efficacy and the instruments used to measure it have become consolidated in the literature, and general self-efficacy has been regarded as a valid indicator of psychological adjustment of individuals. General self-efficacy has shown validity with other constructs, i.e., self-regulation, assessment of stress, depression, and anxiety (Luszczynska, Gutiérrez-Dona, \& Schwarzer, 2005).

The association between these indicators of psychological adjustment and aspects of family environment has been demonstrated in some studies conducted in the 1990s. A U.S. study found positive relations between quality of family relationships and evaluation of selfworth and ability to perform a variety of tasks or deal with different situations (Oliver \& Paull, 1995). In addition, an epidemiological study conducted in Australia indicated that the perception of greater general self-efficacy was demonstrated by youths whose families were seen as being warm, loving, caring, and having good communication (Hoeltje et al., 1996). More recently, high levels of cohesion and low levels of family conflict were associated with high self-esteem in Hispanic youths (Dennis, Basañez, \& Farahmand, 2010). A study based on a growth curve model found that belonging to emotionally connected families was related to increased selfesteem in U.S. adolescents over time (Baldwin \& Hoffmann, 2002).

In Brazil, two studies (Baptista, Alves, \& Santos, 2008; Weber, Stasiak, \& Brandenburg, 2003) identified the association between family variables and indicators of adjustment. In the study by Weber et al. (2003), emotional expressiveness among family members was associated 
with perception of self-worth (Weber et al., 2003). In the study by Baptista et al. (2008), the dimensions affection (closeness and bonding among individuals, equivalent to cohesion), adjustment (no criticism and aggressiveness, equivalent to low conflict), and family autonomy (freedom and privacy among the family members) were related to general self-efficacy.

It is noteworthy that most of the studies mentioned above used methods less robust correlation analysis. Recently, advances in the studies on this theme have been possible with use statistical techniques such as structural equation modeling. A theoretical model in which parental variables (psychological control, psychological autonomy, and acceptance) were predictive of self-esteem has been proposed (Bean \& Northrup, 2009). Additionally, a model in which parenting support (affection and nutrition), psychological control and monitoring were associated with self-esteem and general self-efficacy (Frank et al., 2010) was confirmed. Conversely, studies testing family environment variables (cohesion, hierarchy, support, and conflict) in predicting psychological adjustment are still scarce.

Based on these considerations, there is evidence that the functional family relationship fosters psychological adjustment; however, further studies assessing the direction of this association based on family environment variables are needed. In this sense, the main objective of the present study was to test a theoretical model in which family environment predicts psychological adjustment in adolescence using structural equation modeling. Our secondary objectives involved the analysis of aspects that are still controversial in the literature and consisted of: (a) establishing whether family cohesion and hierarchy are related dimensions, (b) identifying whether there are differences in adolescents scores in terms of cohesion, support, hierarchy, and family conflict, and (c) assessing whether there are differences by sex and age in the variables studied.

\section{Method}

\section{Participants}

Participants were 656 adolescents $(61.1 \%$ girls $)$ aged between 12 and 18 years $(M=15.12, S D=1.52)$. They were enrolled between the $7^{\text {th }}$ grade of elementary school and the $2^{\text {nd }}$ year of high school at public schools of the city of Porto Alegre, capital city of the state of Rio Grande do Sul, Brazil.

\section{Instruments}

The participants completed the Brazilian Youth Questionnaire (Questionário da Juventude Brasileira [QJB], Dell'Aglio, Koller, Cerqueira-Santos, \& Colaço, 2011), which consists of 77 questions aimed at investigating risk and protective factors in adolescence. In the present study, we used only the question 74, comprising the items of the Rosenberg Self-Esteem Scale (Rosenberg, 1965), based on the adaptation by Hutz and Zanon (2011), and the question 75, comprising the items of the Generalized Self-efficacy Scale, created by Schwarzer and Jerusalém (1995) and adapted by Sbicigo, Teixeira, Dias abd Dell'Aglio (2012).

The Rosenberg Self-Esteem Scale ([RSES], Rosenberg, 1965, based on the adaptation by Hutz \& Zanon, 2011) evaluates self-esteem using ten closed questions that assess positive aspects (e.g.: "I think I have many good qualities") and negative aspects (e.g.: "All things considered, I feel a failure") of self-worth. The questions are arranged in a five-point Likert format, ranging from "Never" to "Always." We tested the structure of the RSES in this study because its factor structure is controversial regarding the one- or two-dimensional characteristic of self-esteem. The model showing the best statistical adjustment was the two-factor model $(\mathrm{CFI}=.94, \mathrm{TLI}=.92$, RMSEA $=.08$ ). Cronbach's alpha was .83 for positive selfesteem and .78 for self-depreciation.

The Generalized Self-Efficacy Scale ([GSES], Schwar-zer \& Jerusalém, 1995, adapted by Sbicigo et al., 2012) investigates the perception of personal competence based on ten items such as: "If I have a problem, I usually find a way out" and "I find it easy to persist in my intentions and achieve my goals," with response options in the four-point Likert format ranging from "Not true about me" to "Totally true about me." Cronbach's alpha value was .88 .

The Family Climate Inventory (Inventário do Clima Familiar [ICF]), developed and validated by Teodoro et al. (2009), was used to assess the quality of family relationships. The ICF is made up of the subscales cohesion (5 items), hierarchy (6 items), support (5 items), and conflict (6 items), which are distributed in 22 items arranged in a five-point Likert format, ranging from "I do not agree at all" to "I fully agree." Examples of questions are: "People feel close to each other", "We try to help family members when we realize they have problems" and "People criticize each other often." Cronbach's alpha values were: cohesion $(\alpha=.82)$, support $(\alpha=.68)$, hierarchy $(\alpha=.67)$, and conflict $(\alpha=.87)$.

\section{Procedures and Ethical Considerations}

The research project was approved by the Research Ethics Committee of the university (Protocol No. 2009060). Cluster sampling was used to choose the participating schools. Thus, a list of all public schools in the city of Porto Alegre was prepared ( 350 schools). Thirteen schools were randomly selected from this list, and one refused to participate, totaling 12 schools. Data collection was completed with 12 schools because the required number of participants was reached. The number of participants was determined based on sample calculation (Barbetta, 2001), with a margin of error of $4 \%\left[n_{0}=1 /\right.$ $\left.(.04)^{2}=625\right]$, considering the total number $(N=194.124)$ of students enrolled in primary and secondary education in the public schools of the city. The calculation formula 
was $n=N . n_{0} / N+n_{0}$. A mean of 50 adolescents from each school participated in the study.

The management team of each school selected was contacted and the objectives of the study were presented. Students were invited to participate in the study and were informed that their participation was voluntary, they could drop out from the study at any time, and confidentiality of personal data was ensured. Students received an Informed Consent (IC) form to be returned after being signed by parents or guardians, and the adolescents signed an informed assent. Only students who returned the signed IC participated in the study. The administration of instruments was always performed in the presence of a master's degree student in psychology and at least two research assistants. The instruments were collectively administered in the classroom and the administration lasted for 75 minutes.

\section{Data Analysis}

Data analysis consisted of descriptive calculations, Pearson bivariate correlations, and Student's $t$ test. Structural equation modeling (SEM) with Maximum Likelihood estimation method was used to test the hypothesis that family climate predicts psychological adjustment in adolescence. In SEM, we used reversed scores of hierarchy and conflict so that the latent construct family climate represented a positive climate. Similarly, self-deprecation items were reversed so that this construct was also an indicator of psychological adjustment. An equivalent model, but with opposite direction (psychological adjustment predicting family climate), was also tested for comparison.

The analysis of the models was based on the magnitude of the prediction of one construct in relation to the other and on the main indices of goodness-of-fit: chisquare $\left(\chi^{2}\right)$, chi-square/degrees of freedom $\left(\chi^{2} / d f\right)$, Root Mean Square Error of Approximation (RMSEA), Comparative Fit Index (CFI), Tucker-Lewis Index (TLI), and Akaike Information Criterion (AIC). $\chi^{2}, \chi^{2} / d f$ and RMSEA are considered indicators of absolute fit, i.e., they indicate whether the theoretical model reproduces the observed data. The value of $\chi^{2}$ should have a non-significant $p$; however this measure is sensitive to sample size with a tendency to reject any model in large samples or accept a bad model fit in small samples. For this reason, $\chi^{2}$ should not be interpreted alone. Instead, it should be analyzed together with other indicators of fit. The ratio chi-square/ degrees of freedom $\left(\chi^{2} / d f\right)$ should be lower than 3 and the value of RMSEA should be between .03 and .08 , with $95 \%$ confidence interval. Values lower than .05 are considered excellent fit. RMSEA has advantages because it tries to correct the statistical tendency of $\chi^{2}$ to accept or reject models based on the sample size. CFI and TLI are incremental adjustment indicators that compare the estimated model with a null model, considering values closer to one model as indicators of adequacy of fit. Thus, TLI and CFI values starting at .90 are considered satisfactory. Finally, the AIC index is used to compare the adequacy of one model over another model, and the model with the lowest value is considered the best model (Hair, Black, Babin, Anderson, \& Tatham, 2009).

\section{Results}

\section{Preliminary Analyses}

Initially, we investigated the adolescents' family arrangement and whether this factor could produce differences between the students' means on the instruments. About $52 \%(n=340)$ of participants came from nuclear families, $13.5 \%(n=88)$ had a reconstituted family, $30.3 \%(n=198)$ came from a single-parent family, and $4.6 \%(n=30)$ lived with other relatives and/or with a partner. There was no significant difference in the variables studied in terms of family composition.

Table 1 shows the descriptive analysis of the ICF (subscales), RSES, and GSES. In order to compare the adolescents' scores on the ICF subscales, we calculated the arithmetic mean of cohesion, support, hierarchy, and conflict, considering the number of matched items. We found that the means of cohesion $(M=3.89 ; S D=.94)$, support $(M=3.66 ; \mathrm{S} D=.85)$, and hierarchy $(M=2.89$; $S D=.83$ ) were significantly higher than the mean of family conflict $(M=2.00 ; \mathrm{S} D=.71)$, with $p<.01$. None of the variables correlated with age or differed by gender.

Table 1

Means and Standard Deviations of Ratings on the ICF, RSES and GSES (N=656)

\begin{tabular}{lccccc}
\hline Instruments & Male & Female & Min. & Max. & Total \\
\hline ICF - Cohesion & $19.73(4.60)$ & $19.40(4.81)$ & 5.00 & 25.00 & $19.52(4.73)$ \\
ICF - Hierarchy & $17.61(4.71)$ & $17.06(5.18)$ & 5.00 & 25.00 & $17.27(5.00)$ \\
ICF - Support & $18.37(4.28)$ & $18.22(4.29)$ & 6.00 & 30.00 & $18.27(4.28)$ \\
ICF - Conflict & $11.52(5.29)$ & $10.97(5.79)$ & 6.00 & 30.00 & $11.07(5.60)$ \\
RSES - Self-esteem & $25.36(4.91)$ & $24.77(4.88)$ & 6.00 & 30.00 & $25.00(4.90)$ \\
RSES - Self-depreciation & $16.58(3.60)$ & $16.16(3.57)$ & 4.00 & 20.00 & $16.32(3.59)$ \\
GSES - Self-efficacy & $32.96(6.17)$ & $33.27(5.96)$ & 10.00 & 40.00 & $32.88(6.10)$
\end{tabular}


Sbicigo, J. B. \& Dell'Aglio, D. D. (2012). Family Environment and Psychological Adaptation in Adolescents.

The Pearson correlations between all pairs of variables (Table 2) varied from moderate to weak. Positive selfesteem showed slightly higher correlations with family climate than with self-efficacy. Also noteworthy is that cohesion and hierarchy appeared as independent dimensions.

Table 2

Intercorrelations Among the Variables Investigated $(N=656)$

\begin{tabular}{lccccccc}
\hline & 1 & 2 & 3 & 4 & 5 & 6 & 7 \\
\hline 1 ICF - Cohesion & 1.00 & -.02 & $.68^{* *}$ & $-.38^{* *}$ & $.42 * *$ & $-.27^{* *}$ & $.26^{* *}$ \\
2 ICF - Hierarchy & & 1.00 & .03 & $.48^{* *}$ & -.02 & $.20^{* *}$ & $-.30^{* *}$ \\
3 ICF - Support & & & 1.00 & $-.21^{* *}$ & $.39 * *$ & $-.24^{* *}$ & $.28^{* *}$ \\
4 ICF - Conflict & & & & 1.00 & $-.19 * *$ & $.27 * *$ & $-.16^{* *}$ \\
5 RSES - Positive self-esteem & & & & & 1.00 & $-.44^{* *}$ & $.46^{* *}$ \\
6 RSES - Self-depreciation & & & & & & 1.00 & $-.22^{* *}$ \\
7 GSES - Self-efficacy & & & & & & 1.00 \\
\hline
\end{tabular}

$* * p<.001$.

\section{Structural Equation Model}

With the main objective of our study in mind, we tested a theoretical model representing the association between family environment and psychological adjustment in adolescence. Using the structural modeling technique, we hypothesized that family climate (cohesion, support, hierarchy, and conflict) can predict psychological adjustment (self-esteem and self-efficacy). The results are shown in Table 3.

Table 3

Fit Statistics of the Models

\begin{tabular}{lccccccc}
\hline & $\chi^{2}$ & $p$ & $\chi^{2} / d f$ & RMSEA (90\% IC) & CFI & TLI & AIC \\
\hline Environment -> Adaptation (model 1) & 1850.60 & $<.01$ & 2.27 & $.044(.041-.047)$ & .89 & .88 & 2116.64 \\
Environment -> Adaptation (model 2) & 1320.82 & $<.01$ & 2.24 & $.044(.040-.047)$ & .92 & .91 & 1548.82 \\
Adaptation -> Environment (model 3) & 1394.50 & $<.01$ & 2.37 & $.046(.043-.049)$ & .91 & .90 & 1622.46
\end{tabular}

In this model (model 1), the value of $\chi^{2}$ suggested a poor fit. However, because this measure is sensitive to sample size, other indicators should be analyzed. The ratio $\chi^{2} / d f$ was adequate, indicating that the specified model reproduces the observed data. However, the incremental fit indices CFI and TLI showed values below the critical point of .90 . The absolute fit index RMSEA showed a value in accordance with the literature (Hair et al., 2009). The magnitude of the prediction of family climate in relation to psychological adjustment was moderate $\left(R^{2}=.56\right)$; however, we found that hierarchy had a low and non-significant regression weight, which led us to test a second model (model 2) from which this construct was excluded.

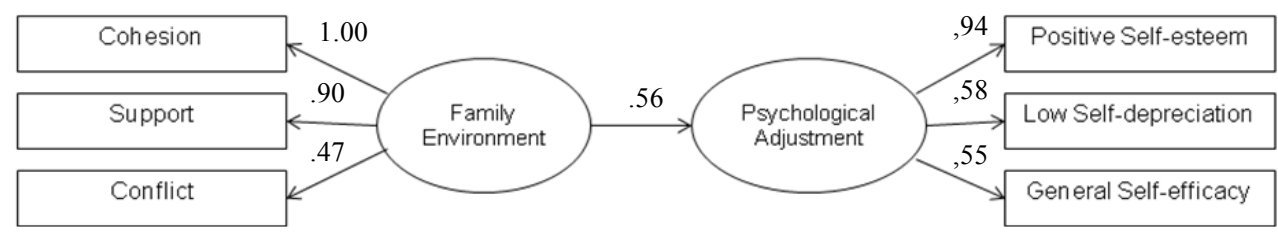

Figure 1. Structural model representing the association between family environment and psychological adaptation. The parameters shown are standardized regression weights with $p<.001$.

In model 2 (Figure 1), the value of $\chi^{2}$ was significant. The ratio $\chi^{2} / d f$ was adequate and the rates of incremental adjustment CFI and TLI achieved satisfactory values. The absolute fit index RMSEA was almost identical to the one in the previous model. The magnitude of prediction of family environment in relation to psychological adjustment remained unchanged $\left(R^{2}=.56\right)$. 
To demonstrate the relevance of the proposed model, an equivalent model (model 3) in which psychological adjustment predicts family climate was tested. In this case, the magnitude of prediction was small $\left(R^{2}=.29\right)$ and adjustment indicators were very similar to the model 2 . The AIC index used for comparison showed that the model 2 shows slightly more parsimonious. Given that the models 2 and 3 did not differ substantially as to fit to the empirical data, we maintain the relevance of the model proposed in this study (model 2), since there is other evidence in the literature that family variables are predictors of psychological adaptation (e.g. Bean \& Northrup, 2009; Frank et al., 2010).

\section{Discussion}

The main objective of the present study was to test a theoretical model in which family environment predicts psychological adjustment in adolescents. The results revealed that cohesion, support, and lower rates of family conflict were significant predictors of psychological adjustment (self-esteem and general self-efficacy) in the sample studied. An equivalent model in which the direction of the association was reversed had less predictive capacity and no advantage as to the adequacy of the fit compared to the proposed structural model.

The association between the constructs (family environment and psychological adjustment) can be explained based on the Symbolic Interactionism Theory ([SIT], (Charon, 1989). According to the SIT, the individual's self-assessment is based on the feedback received from significant people (e.g.: parents). Social interactions are central to the development of the self, which is a social construct built through interaction with others. Significant people would be like a "social mirror" to which the individual would look in order to identify opinions about himself, which are internalized, contributing to the formation of his self-esteem. In this sense, it is likely that adolescents from cohesive and supportive families feel approved, accepted, and loved by family members, creating a feeling of self-worth and confidence in personal capabilities. Additionally, supportive families can be sources of feedback that foster the development of cognitive, emotional, and behavioral repertoires so that adolescents can deal with different situations in an effective manner (Hoeltje et al., 1996). Petersen (2005) noted that children who internalize affirmative and uplifting messages from their parents acquire a strong basis from which they feel capable of setting and achieving goals. In addition, lower levels of conflict, i.e., less criticism and aggressive behavior among family members should contribute to strengthening the self-concept.

The perception of lower family hierarchy was not a relevant variable in the structural model proposed. In the bivariate analysis, however, there was correlation between hierarchy and self-depreciation. It is noteworthy that the hierarchy items of the ICF refer to relationships in which older people have greater authority or in which family members act with authoritarianism and the children have little power of decision. Families with these characteristics tend not to encourage dialogue with their children, which can lead to a perception that parents do not value their opinions or do not believe in their competences. In the 1990s, Weiss and Schwarz (1996) mentioned that authoritarian family behaviors are associated with low selfesteem in children.

This study provides evidence that positive perceptions of family relationships may contribute to psychological adjustment. However, it is important to note that the family environment is a shared environment, since individuals share genes, experiences, beliefs and they are exposed to how parents express affection, establish relations of hierarchy, among others. Plomin (2011) points out, on empirical evidence base, that individual differences in psychological characteristics are best explained by environmental factors unshared, or unique experiences lived in the family as a differential relation with parents and/ or with siblings, as well as extrafamilial experiences with friends, for example. The unique experiences lived with family members would be explained by shared genes that interact in the relations between them. Thus, it is important to be cautious in claiming that a positive family environment predicts psychological adjustment, because the perception that the individual has that environment is constituted mainly by non-shared family experiences (Plomin, 2011). Thus, young people of the same family may have different perceptions about the relationship with the family and therefore express different levels of psychological adaptation.

As for the secondary objectives of the present study, cohesion and hierarchy proved to be independent constructs. This finding suggests that the perception of rules and differentiation of power among family members does not necessarily imply a stronger or weaker emotional bond in the family. Furthermore, we found that the means of family conflict were lower than those found in the other subscales. Classical psychological theories (neopsychoanalytic, sociobiological, and cognitive) emphasize that there is less perceived emotional closeness and a higher rate of conflict with parents during adolescence, which was observed in some international studies with U.S. and European youths (Goede et al., 2009; Matjasko et al., 2007). Conversely, this study found a different result, because cohesion and family support had the highest means. This difference between the studies may be explained, in part, by cultural reasons, since the "familism", a construct that is similar to that of family cohesion is a central characteristic in Latin American cultures, differing from cultures that are considered less collectivist such as the U.S. culture (Cauce \& Domenech-Rodríguez, 2002).

Finally, there were no differences by gender and age on the variables. Studies with adolescents in Rio Grande do Sul (Teodoro et al., 2009; Teodoro, Cardoso, \& Freitas, 2010) found the same result in relation to family environ- 
Sbicigo, J. B. \& Dell'Aglio, D. D. (2012). Family Environment and Psychological Adaptation in Adolescents.

ment, which is opposite to that seen in adolescents in the U.S. (Goede et al., 2009; Matjasko et al., 2007; Veleska et al., 2009). With respect to psychological adjustment, self-esteem and general self-efficacy did not differ by sex and age as well as other studies (Baptista et al., 2008; Gentile et al., 2009; Souza \& Souza, 2004), suggesting that these psychological characteristics are relatively stable in adolescence for boys and girls.

\section{Final Considerations}

The present study provides advances because it investigates family environment, self-esteem, and general selfefficacy involving a representative sample of adolescents from public schools of Porto Alegre, Rio Grande do Sul. This is because the available knowledge on the subject comes mainly from U.S. studies. In the international literature, efforts have been made to address the perception of family environment in adolescence, but there are few studies on this issue in Brazil. We suggest that longitudinal studies with random samples from different regions of Brazil are conducted.

However, our conclusions should be interpreted with caution because this is a cross-sectional study, and cause/ effect relationships cannot be inferred although a structural modeling was used. From the methodological point of view, it is important to emphasize that we only used quantitative self-report instruments. The use of multimethodological techniques to maximize the ecological validity of the results is recommended. Additionally, our findings are only related to data of adolescents from public schools. Therefore, potential differences or similarities between the adolescents included in our sample and those from private schools are unknown. It is also worth mentioning that the present study was conducted only with adolescents who returned an IC form signed by their parents, therefore we do not have information on the characteristics of those adolescents who did not return the form. However, even though there are limitations, the present study contributes to the literature by suggesting that the positive perception of family environment is a predictor of psychological adjustment in adolescents.

Finally, we should emphasize that research on selfesteem and self-efficacy in adolescence is warranted by its relationship with a variety of indicators of adjustment. Low self-esteem and self-efficacy have been related to anxiety, depression, and stress (Luszczynska et al., 2005). It is probable that perceptions of self-worth and personal competence are associated with other behaviors or clinical diagnoses that have not been addressed so far. According to this perspective, it is important to conduct further studies on aspects related to emotional well-being for the promotion of conditions that contribute to the development of positive self-assessment among youths. As noted in the present study, there is evidence that family relationships have the potential to contribute to psychological adjustment in this period of human development.

\section{References}

Baer, J. (2002). Is family cohesion a risk or protective factor during adolescent development? Journal of Marriage and Family, 64, 668-675.

Baldwin, S. A., \& Hoffmann, J. P. (2002). The dynamics of self-esteem: A growth-curve analysis. Journal of Youth and Adolescence, 31(2), 101-113.

Bandura, A. (1977). Self-efficacy: Toward a unifying theory of behavioral change. Psychological Review, 84, 191-215.

Bandura, A. (2006). Adolescent development from an agentic perspective. In F. Pajares \& T. Urdan (Eds.), Self-efficacy beliefs of adolescents (Vol. 5, pp. 1-43). Greenwich, CT: Information Age.

Baptista, M. N., Alves, G. A. S., \& Santos, T. M. M. (2008). Suporte familiar, auto-eficácia e lócus de controle: Evidências de validade entre os construtos. Psicologia: Ciência e Profissão, 28(2), 260-271.

Barbetta, P. A. (2001). Estatística aplicada às ciências sociais. Florianópolis, SC: Editora da Universidade Federal de Santa Catarina.

Bean, R. A., \& Northrup, J. C. (2009). Parental psychological control, psychological autonomy, and acceptance as predictors of self-esteem in Latino adolescents. Journal of Family Issues, 30(11), 1486-1504.

Björnberg, Å., \& Nicholson, N. (2007). The Family Climate Scales: Development of a new measure for use in family business research. Family Business Review, 20(3), 229-246.

Boucher, H. C., Peng, K., Shi, J., \& Wang, L. (2009). Culture and implicit self-esteem: Chinese are "good" and "bad" at the same time. Journal of Cross-Cultural Psychology, 40, 24-45.

Buist, K. L., Reitz, E., \& Dekovic, M. (2010). Attachment stability and change during adolescence: A longitudinal application of the Social Relations Model. Journal of Social and Personal Relationships, 27(1), 351-366.

Cauce, A. M., \& Domenech-Rodriguez, M. (2002). Latino families: Myths and realities. In J. M. Contreras, K. A. Kerns, \& A. M. Neal-Barnett (Eds.), Latino children and families in the United States (pp. 5-25).Westport, CT: Praeger Press.

Charon, J. M. (1989). Symbolic interactionism: An introduction, an interpretation, an integration. New York: Prentice Hall.

Chedid, M., Romo, L., \& Chagnard, E. (2009). Adolescents and marijuana: Links between the consumption level and family structure, cohesion and power. Annales Médico-Psychologiques, 167(7), 541-543.

Collins,W. A., \& Laursen, B. (2004). Parent-adolescent relationships and inûuences. In R. M. Lerner \& L. Steinberg (Eds.), Handbook of Adolescent Psychology (pp. 331-361). Hoboken, NJ: Wiley.

Dell’Aglio, D. D., Koller, S. H., Cerqueira-Santos, E., \& Colaço, V. F. R. (2011). Revisando o Questionário da Juventude Brasileira: Uma nova proposta. In D. D. Dell'Aglio \& S. H. Koller (Eds.), Adolescência e juventude brasileira: Vulnerabilidade e contextos de proteção (pp. 255-266). São Paulo, SP: Casa do Psicólogo.

Dennis, J., Basañez, T., \& Farahmand, A. (2010). Intergenerational conflicts among Latinos in early adulthood: Separating values conflicts with parents from acculturation conflicts. Hispanic Journal of Behavioral Sciences, 32(1), 118-135.

Frank, G., Plunkett, S. W., \& Otten, M. P. (2010). Perceived parenting, self-esteem, and general self-efficacy of Iranian American adolescents. Journal of Child and Family Studies, 19, 738-746. 
Gentile, B., Grabe, S., Dolan-Pascoe, B., Twenge, J. M., Wells, B. E., \& Maitino, A. (2009). Gender differences in domainspecific self-esteem: A meta-analysis. Review of General Psychology, 13, 34-45.

Goede, I. H. A. de, Branje, S. J. T., \& Meeus, W. H. J. (2009). Developmental changes in adolescents'perceptions of relationships with their parents. Journal Youth Adolescence, $38,75-88$.

Greenberger, E., Chen, C., Dmitrieva, J., \& Farruggia, S. P. (2003). Item-wording and the dimensionality of the Rosenberg selfesteem scale: Do they matter? Personality and Individual Differences, 35, 1241-1254.

Guo, R., Deng, S., Liang, J., \& Yan, Y. (2009). Influence of family factors on self-efficacy of the middle school students in Baise City. Wei Sheng Yan Jiu, 38(3), 320-322.

Hair, J. F., Black, W. C., Babin, B. J., Anderson, R. E., \& Tatham, R. L. (2009). Análise multivariada dos dados (6. ed.). Porto Alegre, RS: Bookman.

Hoeltje, C. O., Zubrick, S. R., Silburn, S. R., \& Garton, A. F. (1996). Generalized self-efficacy: Family and adjustments correlates. Journal of Clinical Child Psychology, 25(4), 446453.

Hutz, C. S., \& Zanon, C. (2011). Revisão da adaptação, validação e normatização da Escala de Autoestima de Rosenberg. Avaliação Psicológica, 10(1), 41-49.

Luszczynska, A., Gutiérrez-Dona, B., \& Schwarzer, R. (2005). General self-efficacy in various domains of human functioning: Evidence from five countries. International Journal of Psychology, 40, 80-89.

Matjasko, J. L., Grunden, L. N., \& Ernst, J. L. (2007). Structural and dynamic process family risk factors: Consequences for holistic adolescent functioning. Journal of Marriage and Family, 69, 654-674.

Musito, G., Jiménez, T., \& Murgui, S. (2007). Funcionamiento familiar, autoestima y consumo de sustancias en adolescentes: un modelo de mediación. Salud Pública México, 49(1), 3-10.

Oliver, J., \& Paull, J. (1995). Self-esteem and self-efficacy: Perceived parenting and family climate and depression in university students. Journal of Clinical Psychology, 51(4), 467-481.

Petersen, G. W. (2005). Family influences on adolescent development. In T. P. Gullotta \& G. R. Adams (Eds.), Handbook of adolescent behavioral problems: Evidence-based approaches to prevention and treatment (pp. 27-55). New York: Springer.

Plomin, R. (2011). Commentary: Why are children in the same family so different? Non-shared environment three decades later. International Journal of Epidemiology, 40(3), 582-592.

Rosenberg, M. (1965). Society and the adolescent self-image. Princeton, NJ: Princeton University Press.

Sbicigo, J. B., Teixeira, M. A. P., Dias, A. C. G., \& Dell'Aglio, D. D. (2012). Propriedades psicométricas da Escala de Autoeficácia Geral Percebida. Psico, 43(2), 139-146.

Schwarzer, R., \& Jerusalem, M. (1995). Generalized SelfEfficacy Scale. In J. Weinman, S. Wright, \& M. Johnston (Eds.), Measures in health psychology: A user's portfolio. Causal and control beliefs (pp. 35-37). Windsor, UK: NferNelson.

Skaalvik, E. M., \& Bong, M. (2003). Academic self-concept and self-efficacy: How different are they really? Educational Psychology Review, 15, 1-40.
Smetana, J., Campione-Barr, N., \& Metzger, A. (2006). Adolescent development in interpersonal and societal contexts. Annual Review of Psychology, 57, 255-284.

Souza, I., \& Souza, M. A. (2004). Validação da Escala de Autoeficácia Geral Percebida. Revista Universidade Rural: Série Ciências Humanas, 26(1-2), 12-17.

Teodoro, M. L. T., Allgayer, M., \& Land, B. R. (2009). Desenvolvimento e validade fatorial do Inventário do Clima Familiar (ICF) para adolescentes. Psicologia: Teoria e Prática, 11(3), 27-39.

Teodoro, M. L. T., Cardoso, B. M., \& Freitas, A. C. H. (2010). Afetividade e conflito familiar e sua relação com a depressão em crianças e adolescentes. Psicologia: Reflexão e Crítica, 23(2), 324-333.

Veleska, Z., Geckova, A., Gajdosova, B., Orosova, O., VanDijk, J., \& Reijneveld, S. (2009). Self-esteem and resilience: The connection with risky behavior among adolescents. Addictive Behaviors, 34, 287-291.

Weber, L. N. D., Stasiak, G. R., \& Brandenburg, O. J. (2003). Percepção da interação familiar e auto-estima de adolescentes. Aletheia, 17-18, 95-105.

Weiss, L. H., \& Schwarz, C. (1996). The relationship between Parenting types and older adolescents' personality, academic achievement, adjustment, and substance use. Child Development, 67(5), 2101-2114.

Wood, B. (1985). Proximity and hierarchy: Orthogonal dimensions of family interconnectedness. Family Process, 24, $497-$ 507.

Zimmerman, B. J., \& Cleary, T. J. (2005). Adolescents' development of personal agency: The role of self-efficacy beliefs and selfregulatory skill. In F. Pajares \& T. Urdan (Eds.), Self-efficacy beliefs of adolescents (pp. 45-69). Greenwich, CT: Information Age. 